\title{
Piotr Bylica
}

\section{Mark Harris as a Naturalistic Theist: The Perspective of the Model of Levels of Analysis ${ }^{1}$}

\section{Introduction}

In 2013, Harris published a book entitled The Nature of Creation: Examining the Bible and Science. ${ }^{2}$ This title, however, can be considered a dominant theme of a number of his publications dealing with the relation between science and religion (understood as the Judeo-Christian theism). According to Jitse van der Meer, in this book "Harris offers a clear view of the relation of Bible and science and treats it evenhandedly". ${ }^{3}$ This paper critically reviews Harris's publications dealing with the problems from this area and shows that they do not treat science and Christian theism evenhandedly with respect to the problem of the naturalistic assumptions of science. The focus is on the aspects of his approach that are consistent with naturalistic theism which accepts naturalistic assumptions of science and denies dualist and interventionist assumptions of traditional Christian theism. To that end, the model of level of analysis

\footnotetext{
${ }^{1}$ The article is a part of the project "The application of the model of levels of analysis in the studies of the contemporary naturalistic theism on the relation between natural and supernatural" supported by Poland's National Science Center (decision no. DEC-2013/09/B/HS1/00700). This article was written as a result of the Visiting Research Fellowship in The Institute for the Advanced Studies in the Humanities and the Visiting Fellowship in The School of Divinity, University of Edinburgh in the period between March and April 2014.

${ }^{2}$ See Mark Harris, The Nature of Creation: Examining the Bible and Science, Acumen, Durham 2013.

${ }^{3}$ Jitse van der Meer, "Review (Mark Harris, The Nature of Creation: Examining the Bible and Science, Acumen, Durham 2013)”, ESSSAT News \& Reviews 2015, vol. 25, no. 4, p. 27 [2427].
} 
is used to present the main tenets of naturalistic theism as these manifest themselves in Harris's analyses. This also allows an identification of the distinctive features of his approach. Hence, the aim of the paper is the presentation of Mark Harris's ideas with regard to the relations between science and religion as located within the framework of naturalistic theism.

Naturalistic theism (NT) (or theistic naturalism) is currently a dominant position in terms of the discussion on the relation between science and religion, both in academia and outside. The common assumptions accepted by naturalistic theists are as follows: 1) the acceptance of the contemporary scientific picture of the world; 2) the acceptance of the role of methodological naturalism in science; 3 ) the division of epistemic competence of science and theology where science (with its naturalistic assumptions) is viewed as the only competent source of knowledge on the events occurring in the empirical sphere; 4) the rejection of interventionism. In general, NT accepts naturalistic assumptions of contemporary science and attempts to reconcile Christian doctrine with these. It denies that there is an inherent conflict between science and religion and at the same time presents a modification of classical Christian theism. This modification for the most part involves a rejection of the concept of empirically detectable divine action in nature, as well as a dualist interpretation of the mind-body problem. It reduces concepts of divine action to statements expressed in metaphysical terms.

The proponents of naturalistic theism include pure scientists, academics with both scientific and theological backgrounds, philosophers, clergymen and theologians of different Christian denominations. The list of the most prominent representatives includes Ian G. Barbour, Arthur R. Peacocke, John C. Polkinghorne, George Ellis, George V. Coyne, Ernan McMullin, Francisco Ayala, Kenneth R. Miller, Nancey Murphy, Howard Van Till, John F. Haught, David Griffin, Philip Clayton and Robert J. Russell. In Poland, Michał Heller and Józef Życiński are considered the most influential figures. The diversity of denominations represented within theistic naturalism and its vigorous development, as witnessed by a large number of papers published in the area, shows that there is a common need across Christianity to accommodate Christian beliefs to criteria of rationality adopted in the sciences. 
Mark Harris is trained both in science and theology, in this respect resembling many of the supporters of naturalistic theism mentioned above. ${ }^{4}$ As a physicist, he is known as a co-discoverer, with Steve Bramwell, of the socalled "spin ice", a discovery that heavily influenced the research on magnetism. In 1999, Harris decided to train for ordained ministry and currently is a minister of the Anglican Church and a member of the Doctrine Committee of the Episcopal Church of Scotland. He is also a lecturer in Science and Religion at the University of Edinburgh.

Harris distinguishes himself among other scientists-theologians and naturalistic theists by his use of biblical scholarship in the analysis of particular problems dealing with the relation between science and religion. Harris makes a competent use of biblical material, shows awareness of the complexity of the problems related to biblical hermeneutics and of contemporary discussions in the field. Harris offers a developed version of naturalistic theism, and that is why his publications are worth deeper analysis.

Harris emphasizes the contribution made by prominent proponents of naturalistic theism, yet highlights the need for further development in the area (some of his postulates are presented in the subsequent part of this article). In his own words: "The «classical» field of Science and Religion, defined by the work of scholars such as Ian Barbour, Arthur Peacocke, John Polkinghorne from the 1960 s to the early 2000 s, is being rapidly superseded these days, as we discover more and more crucial areas of engagement between the two disciplines". ${ }^{5}$ In Harris's publications, this development takes a form of an analysis of specific problems within the general frames, which have already been investigated by the abovementioned scholars. His analysis include interpretations of biblical descriptions and of the theological side of problems such as the creation of the world, the fall, and the status of humans in creation, the emotional life of an

\footnotetext{
${ }^{4}$ See Piotr Bylıca, "Główne założenia i problemy teizmu naturalistycznego w sprawie relacji sfery nadprzyrodzonej i świata przyrodniczego" [Main Assumptions and Problems of Naturalistic Theism with Regard to the Relation Between Supernatural and Natural World], in: Wiesław Dyk (ed.), Sozologia systemowa: Biosfera. Czlowiek i jego środowisko w aspekcie przyrodniczym, filozoficznym i teologicznym, vol. IV, Wydawnictwo Naukowe Uniwersytetu Szczecińskiego, Szczecin 2014, p. 57 [55-95].

${ }^{5}$ See http://www.blogs.hss.ed.ac.uk/science-and-religion/page/2/ (30.06.2014).
} 
inanimate world, The Red Sea Event, the resurrection and eschatological aspects of the future of the Universe, and the ascension of Christ. In his analysis, Harris often refers to a number of the assumptions behind naturalistic theism. As mentioned above, the aim of this article is to describe how these assumptions are represented in his works.

\section{General Characterization of the Model of Levels of Analysis (MLA)}

In what follows, only a general outline of the model is presented. ${ }^{6}$ MLA facilitates showing how different statements found within various religious and scientific systems can all be accommodated in a single model that enables a better understanding of science and religion and allows a comparison of these two domains as well as of varying ideas describing the relation between them. ${ }^{7}$

MLA differentiates between statements found within religion, philosophy and science according to their empirical character, the criterion being their empirical testability. When MLA is treated as typology, then the observational

\footnotetext{
${ }^{6}$ For a more detailed description, the reader is invited to consult Piotr BYLICA, "Levels of Analysis in Philosophy, Religion and Science", Zygon 2015, vol. 50, no. 2, pp. 304-328; Piotr ByLICA, "Zarys modelu poziomów analizy w badaniach relacji nauki i religii", Filozoficzne Aspekty Genezy 2012, vol. 9, pp. 221-253.

${ }^{7}$ Attempts at applying stipulations of contemporary methodology and philosophy of science to the analysis of religion and the relation between science and religion, were made most notably by Ian G. Barbour (see e.g. Ian G. Barbour, Myths, Models and Paradigms: A Comparative Study in Science and Religion, Harper \& Row Publishers New York - Evanston - San Francisco — London 1974, esp. chap. 6-8), Nancey Murphy (see e.g. Nancey C. Murphy, "Theology and Science within a Lakatosian Program", Zygon: Journal of Religion and Science 1999, vol. 34, no. 4, pp. 629-642) and, in Poland, by Kazimierz Jodkowski (see e.g. Kazimierz JodKowski, Metodologiczne aspekty kontrowersji ewolucjonizm-kreacjonizm, Realizm. Racjonalność. Relatywizm, vol. 35, Wyd. UMCS, Lublin 1998; Kazimierz JoDKоwsкI, "NOMA, cudy i filtr eksplanacyjny", Roczniki Filozoficzne 2005, vol. 53, no. 2, pp. 83-103; Kazimierz Jodкоwsкi, "Epistemiczne układy odniesienia i «warunek Jodkowskiego»", in: Anna LATAWIEC and Grzegorz BUGAJAK (eds.), Filozoficzne i naukowo-przyrodnicze elementy obrazu świata. T. 7, Wydawnictwo Uniwersytetu Kardynała Stefana Wyszyńskiego, Warszawa 2005, pp. 108-123; Kazimierz JodKowski, “Dlaczego kreacjonizm jest pseudonauką?", in: Józef Zon (ed.), Pogranicza nauki. Protonauka - paranauka - pseudonauka, Wydawnictwo KUL, Lublin 2009, pp. 317-323). See also ByLICA, "Levels of Analysis...", pp. 306-307.
} 
statements describing specific events and properties of the natural world, or a state of affairs one observes in the so-called "empirical sphere", are characterised by the highest level of empirical testability. These statements describe certain empirical facts or observations but, since all observations are theoryladen, observational statements are not protocol-sentences or judgments of perception etc. expressed in theoretically neutral language, as understood within logical empiricism. Observational statements are both empirical and specific. The statements from the "highest level" are "the farthest" from the most typical observational statements (the lowest level in the model) that provide the point of reference.

The model consists of the following five levels:

1) The level of "the deepest" metaphysics is the level of the most general metaphysical statements on being as such and on the ultimate basis for existence. Statements of this level are totally immune with respect to empirical testing and in this sense have no empirical content. They are also neutral in terms of the statements on the other levels of analysis. For example, it contains statements describing God as a necessary being or positing that it is God who sustains the world in its existence. Such statements are consistent with mutually exclusive positions like nominalism and realism (belonging to Level 2), mindbody dualism and dual aspect monism (Level 3), the stationary state cosmology vs. the Big Bang cosmology (Level 4). These statements are also consistent with any specific statement describing particular events from the lowest (5th) level of analysis.

2) The level of "shallower" metaphysics is the level of metaphysical statements dealing with the general characteristics of reality, like general rationality, intelligibility, statements describing the meaning of life and value statements. It also includes naturalistic statements commonly accepted in contemporary science positing that nature is a closed system of causes and effects and/or that no supernatural factors influence the course of action in the empirical sphere in a way that would be empirically detectable. Statements on this level are also immune with respect to empirical testing. The acceptance of such statements is also not dependent on the empirical experience. The difference between the first two levels is that Level 2 statements often serve as important assumptions form- 
ing the attitude toward the world and behind different kinds of human activities. Some are particularly important assumptions behind science or cognitive activity in general, i.e. the statements on general rationality or intelligibility of the Universe and general statements expressing a naturalistic vision of the empirical sphere. The naturalistic vision includes statements commonly accepted in contemporary science positing that nature is a closed system of causes and effects and no supernatural factors influence the course of action in the empirical sphere in a way that would be empirically detectable. Taken together, such statements express the position of naturalism. These naturalistic assumptions are logically prior to any research within any given branch of science. As a consequence for scientific practice, all scientists only look for naturalistic explanations of all the analyzed events.

3) The level of the ontology of nature embraces philosophical statements on the natural world as adopted within given scientific theories, systems of theories or nonscientific theories of particular domains of nature. Certain statements from this level are integral parts of scientific theories, though usually are only accepted tacitly. This level includes statements describing arguments used in discussing positions like determinism and indeterminism, reductionism and antireductionism, naturalism and supernaturalism, interventionism and anti-interventionism etc. within discussions on particular domains of natural sphere. Statements from this level are often integral — though tacitly accepted — ontological assumptions behind scientific theories. It is this level that contains statements describing quantum and dynamic nonlinear processes as either deterministic or indeterministic; statements deciding the adequacy of reductionist or anti-reductionist, monist or dualist explanations of the human mind; philosophical statements on the randomness of mutations, blind natural selection and undirected character of the process of evolution. It is the level, where the discussion on possibility of interventionist action of the supernatural sphere in particular domains of nature takes place.

The main difference between Level 3 and Level 2 statements is that the former are used as assumptions in particular scientific theories, branches of science or theories describing particular special divine action in nature, while the latter refer to the world in general. 
4) The level of regularity statements includes general scientific or religious empirical statements on the regularities met in the natural (empirical) world. This includes laws and theories as found within science or rules of action of the supernatural sphere in the empirical or the natural worlds. In terms of religion, statements of this kind describe regularities (or relative regularities) connected with the conditions for efficient prayers (as measured by empirical experience), including the empirically verifiable outcomes of miraculous healings or other events that are an outcome of supernatural actions.

Despite the fact that religious rules cannot be claimed identical to the scientific laws and theories, religious beliefs (including Christian theism) do include assumptions that can be described as regularities statements referring to constant or semi-constant relation between the supernatural sphere and particular events found in the natural world. ${ }^{8}$ As an example one might quote the religious practices aiming at influencing gods to ensure the rainfall, successful hunting or fertility. In Christian theism, these include the assumptions behind canonization decrees, decrees describing places or pictures as particularly important for obtaining special graces (e.g. a healing grace). Gospels contain many fragments, where it is either tacitly assumed or explicitly stated that obtaining particular graces depends on having a prior appropriate relation with God, namely a strong faith.

5) The level of observational statements is the level of specific or empirical statements describing a particular event occurring on particular date and in particular place. The examples include: "Moon ascension on such and such day equaled X", "The fossils were found in the layer dated for X years", "Moses crossed the Red Sea together with other Israelites", "Jesus turned water into wine", etc. The statements found on the level that is directly higher are used as a part of explanation of events described by statements found on this level. In case of some of these religious statements, the explanation refers to the supernatural intervention as a cause of such events. The acceptance or rejection of the interventionist position on the higher ( $3 \mathrm{rd}$ ) level of analysis influences the acceptance of a particular explanation given for the events described by the statements from the lowest, empirical, level. One can say that our attitude toward the

\footnotetext{
${ }^{8}$ A more detailed analysis can be found in: BYLICA, "Levels of Analysis...”, pp. 311-320.
} 
interventionist position influences the interpretation of the observed facts and determines the content or meaning of the observational statements describing these facts. Assuming this, an instance of demonic possession would be explained as a result of action of a demonic, nonmaterial, personal being. Alternatively, one can adopt the approach connected with the scientific naturalism and, in that particular case, diagnose a dissociative disorder, explaining it with reference to the factors of biological, sociological and psychological character. At the same time "this case" would not be the same case in strict sense, since the assumptions from the higher levels (Level 2 and Level 3) influence the content of the observation. In this sense an exorcist and an atheist psychiatrist would observe two different facts.

\section{General Description of Naturalistic Theism and Harris's Position from the Point of View of the Model of Levels of Analysis}

Having outlined the MLA, now the general description of naturalistic theism as viewed within the model is being presented. Then it is shown how Harris's position is influenced by the assumptions behind NT.

\section{Metaphysical Levels 1-2}

The core question in distinguishing between naturalistic theism and the traditional Christian theism is the relation between the supernatural and natural: in particular, the problem of how the former relates to and influences the latter. According to Peacocke, the exploration of "[...] the paths from the world of science towards God [...] leads to the advocacy of an open theology seeking integrating perceptions and thus to: a renewed stress on God's immanence in the world and thence to a theistic naturalism and panentheism [...]". ${ }^{9}$ The traditional ideas of supernaturalism, dualism and interventionism are denied:

\footnotetext{
${ }^{9}$ Arthur R. Peacocke, Paths from Science toward God: The End of All Our Exploring, Oneworld, Oxford 2001, p. vii.
} 
The only dualism now theologically defensible appears to be the distinction between the Being of God and that of everything else (the "world" = all-that-is, all-that-is-created). Talk of the "supernatural" as a level of being in the world, other than God, therefore becomes superfluous and misleading, and a genuine naturalism is thus entirely compatible with theism - for God is the only super-natural entity or being. In spite of "naturalism" often being associated with a reductive materialism and opposed to belief in God, a theistic naturalism is entirely defensible. Nouns such as "mind" and "spirit" are best replaced by adjectives (or the corresponding adverbs) such as "spiritual" and "mental" predicating activities and functions of whole persons. For example, in this perspective human beings do not possess some special apparatus, some antenna, which has a non-natural way of interacting with God - some special wavelengths for divine communication - but nevertheless they do naturally have a holistic capacity, a "spiritual" one, to relate to and be aware of God. Similar remarks apply to their possession of the capacity for mental activity. ${ }^{10}$

The processes revealed by the sciences are in themselves God acting as Creator, and God is not to be found as some kind of additional influence or factor added on to the processes of the world God is creating. This perspective can properly be called "theistic naturalism". 11

The proposed model is a useful tool in terms of presentation of the main assumptions behind naturalistic theism, especially when one intends to focus on the adopted division of epistemic competence between science and religion. The model facilitates the identification of the types of supernatural action in nature assumed and rejected within naturalistic theism.

This division scheme is clearly visible in Heller's treatment of the question of the possible gaps in the descriptions of the world. In the context of the problem of the God-of-the-gaps theology, Heller distinguishes between serious and spurious gaps. According to him the "spurious gaps are temporary holes in our knowledge usually referring to an incomplete scientific theory or hypothesis and to restricted domain of phenomena". ${ }^{12}$ Heller admits that the scientific description of the world contains gaps but states that these gaps are not genuine in the

\footnotetext{
${ }^{10}$ Peacocke, Paths from Science..., p. 51.

${ }^{11}$ Peacocke, Paths from Science..., p. 138.

${ }^{12}$ Michał Heller, "Chaos, Probability, and the Comprehensibility of the World", in: Robert J. Russell, Nancey Murphy, and Arthur R. Peacocke (eds.), Chaos and Complexity, Scientific Perspectives on Divine Action, Vatican Observatory Publications and CTNS, Vatican - Berkeley 1995, pp. 120-121 [107-121].
} 
sense that one may expect that sooner or later the gaps will be filled. There is no need, and it is even inappropriate, to invoke God or any other supernatural factors to fill this kind of gaps as science itself is sufficient. According to Heller, the genuine gaps are: the ontological gap - "Why is there something rather than nothing"; the epistemological gap — "Why is the world comprehensible?"; and the axiological gap connected with the value and meaning of existence. ${ }^{13}$

All the statements used in attempts at filling the abovementioned gaps are metaphysical and, as such, devoid of any empirical content. In our model these belong to the first two levels. Using Heller's terminology, statements related to the ontological gap belong to Level 1, while both statements related to epistemological and statements related to axiological gaps belong to Level 2. This is so, because the acceptance of particular Level 2 statements influences the attitude toward the world held by an individual. Such statements also have a practical dimension, non-existent in case of Level 1 statements. The acceptance of the statement on the rationality and comprehensibility of the world underpins scientific study in general. Note, however, that both levels are important for Christian theism: a particular Christian theist might assume that God is the common source of existence, rationality and values.

It should be emphasized that the issues discussed here lie outside the realm of scientific competence: the discussions over such issues belong to philosophy and - especially - to religion. Science deals with particular processes and objects in nature, often referred to as empirical facts. Scientific competence is limited to the empirical sphere. Such facts can be explained using relevant scientific laws and theories. The religious domain, if restricted to Level 1 and Level 2, is of completely different character. On the one hand, science and religion have something to say about the same world, but are interested in completely different aspects of it. Hence, these are the sources of completely different kinds of statements. As Francisco J. Ayala, a prominent naturalistic theist and an example of a thinker supporting the idea of strict separation between science and religion, puts it:

\footnotetext{
${ }^{13}$ Heller, "Chaos, Probability...,", pp. 120-121. See also Stanisław WszoŁek, "W obronie argumentu God of the gaps", Zagadnienia Filozoficzne w Nauce 1999, vol. XXIII, pp. 114-115 [103-118].
} 
Science and religion are like two different windows for looking at the world. The two windows look at the same world, but they show different aspects of that world. Science concerns the processes that account for the natural world: how planets move, the composition of matter and the atmosphere, the origins and adaptations of organism. Religion concerns the meaning and purpose of the world and of human life, the proper relation of people to the Creator and to each other, the moral values that inspire and govern people's lives. ${ }^{14}$

Barbour was also one of the advocates of the division, where facts and explanations of all natural events belong to science and where religion is thought of as not conflicting with the sciences. He wrote: "Belief in God is primarily a commitment to a way of life in response to distinctive kinds of religious experience in communities formed by historic traditions; it is not a substitute for scientific research. Religious beliefs offer a wider framework of meaning in which particular events can be contextualized". ${ }^{15}$ From the point of view of the model of levels of analysis, such a division of epistemic competences tells us that it is religion that can competently deliver Level 1 or Level 2 statements; while science is competent to resolve problems as described by Level 4 and Level 5 statements.

Harris often approvingly refers to such interpretations of the relations between God and the world that express these relations using Level 1 and Level 2 statements. In particular, he quotes the following metaphysical notions: creatio ex nihilo, God's transcendence, the immanence of God in the world, and the continuous creation. In this manner, he interprets the biblical statements which taken as prima facie belong to Levels 3-5 as the symbolic representations of the relation between God and the world. Harris gives the following account of the spatial and temporal order of the world: "[...] many of the Biblical statements which appear to describe the cosmos and its structure are actually symbolic references to the relationship between Creator and creation. [These - PB] [...] describe the divine quality of transcendence $[\ldots]$. [...] biblical ideas of cosmic be-

\footnotetext{
${ }^{14}$ Francisco J. Ayala, Am I a Monkey? Six Big Questions about Evolution, John Hopkins University Press, Baltimore 2010, p. 73.

${ }^{15}$ Ian G. Barbour, When Science Meets Religion, Harper, San Francisco 2000, p. 14.
} 
ginnings and of endings, as well as of historical times in-between [...] are all heavily symbolic in various ways of God's work in the world". ${ }^{16}$

The interpretation of creatio ex nihilo as only describing the relation of ultimate dependence of the world on God, rather than the concept on temporal beginning of the world, is one of the metaphysical concepts popular among naturalistic theists adopted by Harris in his interpretation of the theistic doctrine of creation. ${ }^{17} \mathrm{He}$ also writes about God's transcendence as related to the notion of creatio ex nihilo and stresses that it should be interpreted as implying that God is omnipresent and prevents the world from falling back into nothingness, and hence sustains the world in its existence. ${ }^{18}$ Harris considers the notion of continuous creation as better describing the theistic idea of God's relation to the world than creatio ex nihilo also because "deism can affirm God's general providential support of the world, without believing that God interacts closely with its activity". ${ }^{19}$ The idea of the closeness between God and the world seems to be very important for the theistic doctrine. However, such a notion of closeness is a purely metaphysical one from the point of view of MLA, as, according to Harris, theism "[...] not only maintains the ex nihilo throughout the history of the world, but also believes God to be immanently present in it (that is, inherent in creation, in close proximity to it". ${ }^{20}$ Harris also characterizes the relation between God and the world in terms of contingency of the world vs. the necessity of God and stresses that the continuous creation expresses the theistic idea of immanence of God in the world. The concept of God's immanence means that God is "present in and with the world, participating in it in an actively creative sense". ${ }^{21}$

The model of levels of analysis shows that the idea of God actively creating in or closely interacting with the world is described by metaphysical (Levels 1-

\footnotetext{
${ }^{16}$ Harris, The Nature of Creation..., pp. 109-110.

${ }^{17}$ See Harris, The Nature of Creation..., p. 112.

${ }^{18}$ See Harris, The Nature of Creation..., p. 112.

${ }^{19}$ HARRIS, The Nature of Creation..., p. 113.

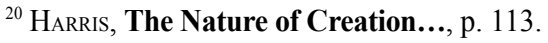

${ }^{21}$ Harris, The Nature of Creation..., p. 115.
} 
2) and not the empirical statements (Levels 4-5). Though, as Harris puts it, the creatio continua view "incorporates elements of chance and emergence" 22 that comes from philosophical implications of contemporary scientific theories or branches of science (Level 3). He adds, however, that "we should be cautious not to identify specific scientific ideas of cosmic or biological evolution with the theological category of creatio continua". ${ }^{23}$ The metaphysical character of this notion is particularly well expressed in the longer quotation below, where Harris directly states that continuous creation and creatio ex nihilo are coherent with all scientific (empirical) notions. According to Harris, if we were to equate a particular notion of creation with a particular scientific idea, then

We would be suggesting that God's continuous creative activity is manifest more in some ways [...] than others: God would appear to be more present immanently through the development of novel forms of life than in already existent forms. Furthermore, we would run the risk of amplifying an unhelpful distinction between creatio continua and creatio ex nihilo, of identifying the former primarily with natural mechanisms, and the latter with supernatural. We must be careful therefore not to imply, that when God creates continuously God's work comes within the remit of science and is natural, while when God creates from nothing it is theological and inherently supernatural. $[\ldots]$

For these reasons it is helpful to affirm both categories [...] as complements, and to affirm them primarily as theological categories without making them reliant on science. [...] Modern science has highlighted the importance of chance and novelty in our understanding of the evolution of the world, and creatio continua allows us to incorporate that idea quite generally into our theology, without pinning it down to a specific scientific model. ${ }^{24}$

In other words, the reconciliation of theology and science with respect to the issue of how God acts in the world relies on accepting such a concept of God's action that is inherently independent of any findings within the empirical sciences. Here, Harris makes use of the idea first proposed by Barbour with respect to the relation between the notion of creatio continua and particular scientific theories. In his influential book Issues in Science and Religion, which defines

\footnotetext{
${ }^{22}$ Harris, The Nature of Creation..., p. 117.

${ }^{23}$ HARRIS, The Nature of Creation..., p. 115.

${ }^{24}$ HARRIS, The Nature of Creation..., p. 119.
} 
the domain and describes the main voices in the discussion of such a relation, Barbour stated that in the discussion between the Big Bang cosmology and the theory of stationary state, " $[\ldots]$ the Christian need not favor either theory, for the doctrine of creation is not really about temporal beginnings but about the basic relationship between the world and God". ${ }^{25}$ In other words, theology can accept any scientific findings describing nature. Despite the fact that Harris does remark on the importance of chance and novelty and on the nondeterministic scientific picture of the world, allegedly influencing the doctrine of God's immanence, it is not difficult to think of a notion of God being immanently present in the - deterministic - natural order.

If we assume that scientific theories do have an empirical character, as they refer to empirical world and are ultimately tested by empirical evidence, then we can interpret the notions like creatio continua and all the ideas describing God's immanence, transcendence, creatio ex nihilo or a very close interaction and engagement of God in the world as unempirical and, hence, as lying outside the competence of science. Such notions have been known to classical philosophy and theology for centuries. Naturalistic theism uses these in attempts at reconciling science with Christian theism. In its strongest form, it seeks to limit the descriptions of the relations between the supernatural and natural to refer only to such kinds of notions that make theistic picture of the natural sphere empirically undistinguishable from the materialistic or deistic pictures.

\section{Philosophical Assumptions from Level 3}

In order to present a complete picture of the approach to science and religion within naturalistic theism one needs to highlight a crucial role played by certain Level 3 philosophical assumptions that impose restrictions on the interpretation of divine action within that doctrine. In particular, some such assumptions influence how science explains certain observable natural phenomena and what kind of religious explanations of given phenomena are acceptable. It is the

\footnotetext{
${ }^{25}$ Ian G. BARBour, Issues in Science and Religion, Harper \& Row, New York - Hagerstown — San Francisco — London 1971, p. 368. See also pp. 376-377.
} 
acceptance of particular Level 3 assumptions that is most important in defining the position of naturalistic theism.

As it was mentioned before, Level 3 contains statements describing the ontological discussions between determinism and indeterminism, reductionism and antireductionism, naturalism and supernaturalism, interventionism and anti-interventionism, etc. within particular branches of science. From the religious point of view, such discussions form an important part of analysis on what aspects of the natural (empirical) world are involved in special divine action. This is important to religion, as it also encompasses the problem of the relation between soul and body, the ontological status of free will and the autonomy of human action, etc. Out of many diverse positions some form accepted philosophical parts of scientific theories or branches of contemporary science, while others are rejected within science. For example, we find reductionist assumptions in neurobiological approach to human consciousness; the indeterministic Copenhagen interpretation of quantum processes; or the assumptions on the role of randomness, chance in biological evolution and on the undirected character of the evolutionary change. In fact, the types of positions within branches of contemporary science listed above always reject supernaturalism and interventionism and assume naturalism (Level 2). Supernaturalism is not an accepted part of the contemporary scientific research practice and, as a consequence, is absent from the scientific picture of the world, from which both the dualism of natural and supernatural (including the duality of mind and body) and interventionist ideas are absent.

The rejection of dualism and interventionism (Level 2), assumed in the statements of the particular domains of sciences (Level 3), is related to the postulate of methodological naturalism: scientific explanations should not use supernatural factors in explaining the natural phenomena. Combining this postulate with the mentioned division of epistemic competences leads to the conclusion that within science any reference either to the interventions of supernatural factors or to nonmaterial soul in describing the events observable in the empirical world are not considered valid. Naturalistic theists disparage any references to the supernatural factors aimed at explaining various events or properties of nature and give such references various names, ranging from capricious God, 
God - the magician to God of the gaps, which is by far the most popular moniker. ${ }^{26}$

Similarly, in relation to the origin and nature of the human soul, naturalistic theists reject at least those interventionist ideas on its origin and nonmaterial character that are related to the notion of dualism of mind and body. They write about the origins of man's spiritual dimension as an expression of potentialities inherent in the matter or an effect of a purely natural process, in which God's role is to sustain this process in its existence. ${ }^{27}$ The ontological status of human

26 "Whatever his relation to his world, it must surely be faithful not capricious, regular rather than intermittent" (John C. Polkinghorne, One World: Interaction of Science and Theology, Templeton Foundation Press, Philadelphia and London 2007, p. 89). According to Kenneth R. Miller, the interventionist account of species creation " [...] does a terrible disservice to God by casting him as a magician who periodically creates and then creates again throughout the geologic ages. [...] God is not a magician who works cheap tricks" (Kenneth R. MILLER, Finding Darwin's God: A Scientist's Search for Common Ground Between God and Evolution, Cliff Street Books, New York 1999, p. 128). The popular phrase "God of the gaps" owes its origins to Dietrich Bonhoeffer. He warned against referring to God as an explanation used in order to fill in the gaps that can be filled in by means of science at some point in the future (see Nicholas SAUNDERS, Divine Action and Modern Science, Cambridge University Press, Cambridge 2002, p. 96). According to Bonhoeffer, it is inappropriate to invoke God when our knowledge is incomplete. In a letter to Eberhard Bethge, he wrote: "[...] how wrong it is to use God as a stop-gap for the in completeness of our knowledge. If in fact the frontiers of knowledge are being pushed further and further back (and that is bound to be the case), then God is being pushed back with them, and is therefore continually in retreat. We are to find God in what we know, not in what we don't know [...]" (Dietrich Bonhoefrer, Letters and Papers from Prison: The Enlarged Edition, SCM Press, London, Letter to Eberhard Bethge, 29 May 1944 [cited in: SAunders, Divine Action..., p. 96]). See also ByLICA, "Zarys modelu...", pp. 231-232.

27 "The emergence of consciousness seems to me to be far the most striking and significant development in all the long cosmic history, but it seems natural to seek to understand it as the full flowering of a potentiality always present, rather than injection from outside (even by benevolent Creator) of a totally new and distinct kind of substance" (John C. Polkinghorne, Beyond Science: The Wider Human Context, Cambridge University Press, Cambridge 2002, pp. 59-60. See also John C. Polkinghorne, One World..., p. 83). Abp. Józef Życiński criticized the idea of interventionist origins of human soul, calling it a "naive anthropomorphism": "This process should not be interpreted in a way dominated by naive anthropomorphisms. These show up when animal-level evolution is understood exclusively in terms of natural selection and only when it comes to the origins of man, a special creative intervention of God would be introduced. God's Logos is immanently present in the entire process of a creative development of the universe. The process of creation is ongoing in every epoch and our "continuing existence» is an expression of this" (Abp. Józef ŻyciŃsKI, Bóg i ewolucja. Podstawowe pytania ewolucjonizmu chrześcijańskiego, Prace Wydziału Filozoficznego, vol. 89, Wyd. TN KUL, Lublin 2002, p. 57). 
soul is usually interpreted either in the spirit of dual-aspect monism that incorporates the two perspectives, or using the notion of emergence (as opposed to reductionism). Natural theists emphasize the importance of the unity of man, as justified by the Bible and the contemporary scientific findings.

According to Harris, "Belief in the soul, as an immaterial entity which encapsulates a person's living identity and carries on into the after life, has been an important component of Christian belief for many centuries. Recent neuroscientific research, however, sheds doubt on this belief". ${ }^{28}$ Hence, Harris indicates that contemporary science can shed a new light on the notion of the human soul, an important part of the traditional Christian doctrine. As naturalistic theists find the idea of unity of man in the Bible as not conflicting with science, Harris too points to the idea of the unity of body and soul and to the idea of the emergence of the cognitive (and presumably also spiritual) states as found in the works of Gregory of Nyssa. Harris, after quoting Gregory of Nyssa as saying that "The soul is an essence created, and living, and intellectual, transmitting from itself to an organized and sentient body the power of living and of grasping objects of sense, as long as a natural constitution capable of this holds together", concludes:

Such a statement is not a million miles from the modern perspective known as "non-reductive physicalism", where the entire human person (including the soul) can be described biologically, but cognitive (and presumably spiritual) states are emergent from it [...]. As Malcolm Jeeves puts it: "According to this view, we regard mental activity as embodied in brain activity rather than as being identical with brain activity" [...]. And certainly Gregory can be read as proposing the soul as a kind of emergent property, escribing the continual becoming of the soul — its metaphorical ascent towards God - as a process which takes place both in this earthly body and in the resurrection body. ${ }^{29}$

The position represented by Gregory of Nyssa is then similar to the more contemporary philosophical notions described by Level 3 statements, accepted

\footnotetext{
${ }^{28}$ The quotation comes from an Abstract of a paper by Mark HARRIS, "Does Jesus Have a Soul?: The Apollinarian Controversy Revisited", in: Michael Fuller (ed.), The Concept of the Soul: Scientific and Religious Perspectives, Cambridge Scholars Publishing, Newcastle upon Tyne 2014, pp. 75-81.

${ }^{29}$ Harris, "Does Jesus Have a Soul...,", p. 79.
} 
in science and associated with scientifically-informed interpretations of the relations between mind and body. Obviously, one also finds a strong reductionistic streak within science; however, such approaches are often criticized and rejected in naturalistic theism. The popular emergentist approach is characterised by Harris as follows:

The soul cannot be reduced to biology, in the same way that theological concepts such as sin cannot be reduced to biology; nevertheless, they are compatible with biology. $[\ldots]$

$[\ldots]$ the soul is human life, mind in body, in ascent towards God (and descent away from God through sin). This view does not conflict with the physicalist approach, since it essentially functions as a theological metaphor which adds a richly theological perspective to the physicalist approach. It resists the tendency of metaphysical naturalism to reduce the human condition to science, while remaining compatible with science. ${ }^{30}$

Harris presents the emergentist idea as having a non-empirical sense (being a theological metaphor), referring to the metaphysical dimension of the relation between man and God. Assuming this kind of meaning of the term "soul" does not contradict the physicalist approach assumed within science. The difference between science and theology is that theology deals with a metaphysical dimension that is absent in science. The scientific picture of the world is incomplete, as it does not determine Level 1 and Level 2 statements. What science has to say - in an authoritative manner - on human mind includes the statements from Levels 5, 4 and 3. Traditional Christian theology was in conflict with contemporary scientific interpretation as the dualist interpretation of the relation between human soul and body (Level 3) was "an important component of Christian belief for many centuries". But when the theological notions are reduced to the metaphysical levels no conflict emerges anymore, or at least it is easy to avoid clashing with any particular scientific theories, since metaphysical statements by definition have no empirical and "scientifically interesting" content. And this is in fact the strategy of naturalistic theists, which is also employed by Harris.

Hence, the essence of the approach to the relation between the supernatural and natural presented within naturalistic theism lies in the rejection of interventionist supernatural action in nature and dualist solutions to the relation between

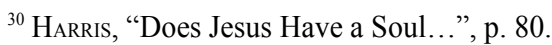


mind and body. It is important to notice that even though naturalistic theists reject interventions but not the possibility of a non-interventionist special divine action in nature. They use certain notions, as described by Level 3 statements, in order to explain how God can influence particular events in the world. Some naturalistic theists, e.g. Nancey Murphy, George F. Ellis, Thomas F. Tracy, Robert J. Russell, John C. Polkinghorne, Arthur R. Peacocke, attempt at "hiding" God's action outside the limits of scientific discovery by using the notion of indeterministically-interpreted quantum processes, the nonlinear dynamic processes or high complexity of systems like human mind. ${ }^{31}$ In this approach, the causal joint of God's action in the world is always related to the situation or such aspects of nature, where this action may take place without being recognized by empirical and scientific procedures.

Recall that Harris also stresses the role of the indeterministic aspects found in scientifically-informed picture of the world in order to explain the notions of God's immanence and creatio continua. All these thinkers deal with the Level 3 philosophical assumptions behind scientific interpretations of the world, reject-

\footnotetext{
${ }^{31}$ See Nancey Murphy, "Divine Action in the Natural Order: Buridan's Ass and Schödinger's Cat", in: Russell, Murphy, and Peacocke (eds.), Chaos and Complexity..., p. 343 [325-358]; see also pp. 341-357; Nicholas Saunders, Divine Action..., p. 115; Robert J. Russell, "Special Providence and Genetic Mutation: A New Defense of Theistic Evolution", in: Robert J. Russell, William R. Stoeger, and Francisco Ayala (eds.), Molecular Biology, Scientific Perspectives on Divine Action, Vatican Observatory and CTNS, Rome - Berkeley 1998, pp. 191-223; Robert J. Russell, "Divine Action and Quantum Mechanics: A Fresh Assessment", in: Robert John Russell, Philip Clayton, Kirk Wegter-McNelly, and John C. Polkinghorne (eds.), Quantum Mechanics, Scientific Perspectives on Divine Action, Vatican Observatory Publications, Center for Theology and the Natural Sciences Vatican City State - Berkeley 2001, pp. 293-328; Robert John Russell, Cosmology: From Alpha to Omega: The Creative Mutual Interaction of Theology and Science, Theology and the Sciences, Fortress Press, Minneapolis 2008, esp. Part II, chap. 4-7, pp. 110-248; Thomas F. Tracy, "Particular Providence and the God of the Gap", in: Russell, Murphy, and Peacocke (eds.), Chaos and Complexity..., pp. 321-322 [289-324]; George Ellis, "Ordinary and Extraordinary Divine Action: The Nexus of Interaction", in: Russell, Murphy, and Peacocke (eds.), Chaos and Complexity..., pp. 387-388 [359-396]; Arthur R. PeAcocke, "God's Interaction with the World: The Implications of Deterministic «Chaos» and of Interconnected and Interdependent Complexity”, in: Russell, Murphy, and Peacocke (eds.), Chaos and Complexity..., p. 285 [263-288]; see also pp. 279-287; John C. Polkinghorne, Science and Providence: God's Interaction with the World, New Science Library, Shambala - Boston 1989, esp. chap. 1-4; John Polkinghorne, "The Metaphysics of Divine Action", in: Russell, Murphy, and Peacocke (eds.), Chaos and Complexity..., pp. 151-156 [147-156]. See also ByLICA, "Levels of Analysis...", pp. 310-311.
} 
ing certain positions, like determinism or reductionism, in relation to science. What is never rejected, however, are the Level 3 philosophical assumptions behind the discussion between naturalism and interventionism and the dualistic (distinguishing two aspects: soul and body) approach as present in particular domains of science and based on naturalistic Level 2 statements on natural world in general.

In order to better understand the Harris's rejection of intervention and how he sees the relation between intervention and theistic doctrine on divine action the very term intervention requires a few words of clarification. Note, however, that this article only tangentially deals with this notion, which demands a more detailed analysis in order to tackle the problem in its full complexity. In the research literature, this term is used to refer to various aspects of God's actions within the empirical sphere. Such aspects can be categorized into three classes: causal, theological and epistemological. Such ways of making use of the term that refer to the mentioned categories are not mutually exclusive and many accounts in fact combine a number of aspects, so that separating the various meanings often requires a more in-depth analysis.

In the causal approach, the interventionist action is understood as action of God that goes against the order of nature as described in sciences, "[...] making difference in the world [...] in a way contrary to those regularities and laws operating within the observed universe, which are explicated by the sciences [...]". ${ }^{32}$ This includes the actions of God resembling natural causes that require matter or energy being added to natural processes. Both violating the laws of nature and God's actions conceived as natural causes (by adding matter or energy) are explicitly rejected within naturalistic theism.

Some authors view the notion of God's interventions as related to the theological problem of God's transcendence, immanence and deistic character of His relation to the world. According to these authors, interventionism is connected to the deistic (and not theistic) understanding of God's relation with the world, as it is seems to assume that God is merely transcendent (and not immanent) to the world. The idea of interventions means that God occasionally acts from beyond

\footnotetext{
${ }^{32}$ Peacocke, “God's Interaction...”, p. 286. Here, I am using a fragment by Peacocke, where he argues for the opposite hypothesis, namely for the noninterventionist notion of God's actions.
} 
the world but in general is not constantly present there. In this context, Harris writes about a "deistic talk of «intervention»". ${ }^{33}$ He quotes Wright's observation that the influence of deism on modern thought is witnessed by the popularity of the concept that the "[...] world is conceived as self-sufficient system largely closed to divine influence; God is normally absent but might intervene occasionally, in radical discontinuity with the world order". ${ }^{34}$ A deist concept of relation between God and the world is alleged to appear when one tries to describe God's action in scientific language: "[...] attempts to articulate divine work in the world using scientific language have a tendency to fall into «god of the gaps» approaches or into a subtle deism, especially when we speak of divine action as an «intervention»". ${ }^{35}$ According to Harris, this kind of understanding of intervention is especially evident in the context of evolution: "In any case, talk of progress or «purpose» in evolution raises theological difficulties of its own, because it implies divine «guidance» behind evolutionary processes, and raises the problems, which flow from deistic talk of divine «intervention»". ${ }^{36}$

The epistemic aspect encompasses the reference to the fact that God's actions in the world are recognizable. Interventions are interpreted as the events caused by God that can be only explained by invoking the special action of God. In most cases, this means such extraordinary events that are, again, "contrary to those regularities and laws operating within the observed universe, which are explicated by the sciences". As this concept assumes incompleteness of scientific (hence naturalistic) account of the natural world, it is rejected by naturalistic theism as such references to God are an example of the God-of-the-gaps theology.

Identifying divine interventions with deism rather than with theism, which is what Harris does, is consistent with the strategy of naturalistic theism to "purify" the theistic doctrine from the notion of empirically recognizable divine action. Yet, the assumption that some divine actions are empirically recognizable

\footnotetext{
${ }^{33}$ See HARris, The Nature of Creation..., pp. 113, 191.

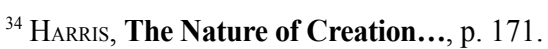

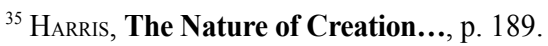

${ }^{36}$ HARRIS, The Nature of Creation..., p. 191.
} 
in nature is important in the classical Christian (but not only Christian) theism. ${ }^{37}$ Hence, the epistemic aspect of divine intervention seems to be the most important in the discussion on the relation between science and religion in general.

\section{The Empirical Levels 4 and 5}

The acceptance of the naturalistic and anti-interventionistic Level 2 and 3 assumptions together with the division of epistemic competence between science and theology influences the interpretation and acceptance (or rejection) of particular religious statements from the empirical Levels 4 and 5 by naturalistic theists. Anyone wanting to be consistent with such assumptions should reject any statements describing events in the natural sphere (Level 5), the appropriate explanation of which involves a supernatural intervention. (Recall that within the traditional Christian theism God is not the only supernatural being acting in the empirical world). Naturalistic theists reject the thesis on empirical recognizability of God's actions in the world. The case of the actions of the other, lower, supernatural entities mentioned in the traditional Christian theism has been, to a large extent, either not dealt with or rejected. (The sole empirical event with regard to which most of the described representatives of NT do not reject the possibility of God's involvement in the world is the embodiment of God in Jesus Christ and his resurrection). Moreover, naturalistic theists must also reject the regularities statements (Level 4) describing the relation between given conditions (in this case, conditions that include e.g. the relation to the supernatural) and such events. As a result, no Level 5 statements that describe such occurrences can be interpreted literally. According to Harris, "[...] all descriptions of

\footnotetext{
${ }^{37}$ Contemporary theological case for divine intervention one finds in e.g. Clive S. LEwIS, Miracles: A Preliminary Study, Collins, Glasgow 1977 (1st ed. 1947); Clive S. Lewis, "Modern Theology and Biblical Criticism", in: Clive S. LewIs, The Seeing Eye: And Other Selected Essays from Christian Reflections, Ballantine Books, New York 1986, pp. 203-223; Clive S. LewIs, "Miracles", in: Clive S. Lewis, The Grand Miracle: And Other Selected Essays on Theology and Ethics from God in the Dock, Ballantine Books, New York 1983; Alvin Plantinga, "Divine Action in the World (Synopsis)", Ratio (New Series) 2006, vol. 19, pp. 495-504; Alvin Plantinga, "Two (or More) Kinds of Scripture Scholarship", Modern Theology 1998, vol. 14, no. 2, pp. 243 278; Alvin Plantinga, "What Is «Intervention»?", Theology and Science 2008, vol. 6, no. 4, pp. 369-401.
} 
divine work are metaphorical [...]". ${ }^{38}$ A closer look at his analysis of particular events described in the Old or New Testaments, which can be interpreted in the literal sense as divine interventions, reveals that Harris is inclined toward the non-literal theological interpretations.

Let us turn now to three examples of the religious statements analyzed by Harris that in the literal sense refer to certain observable events interpreted as effects of supernatural intervention. The discussion, presented above, on creatio ex nihilo and creatio continua contains the first example. Interpreted literally, the quotation from Genesis deals with the temporal beginning of the world and can be of an empirical character as an observable event that took place at a particular moment in time. The notion of the Big Bang as an initial moment of the Universe might be interpreted as scientific, having an empirical interpretation, and which can be compared with a literally interpreted statement describing the creation of the world understood as its temporal beginning. As we have seen, the mentioned metaphysical notions neutralize any possible conflict with a scientific theory for the price of the non-empirical character of an important theological idea.

In another place, Harris analyses the scientific, literary and mythological explanations for the Sea Event as described in Exodus 14. Taken literally, this Biblical account includes Level 5 empirical statements that describe what happened at a particular time and place and assert supernatural intervention. Harris overviews different types of interpretation of this Biblical event, noting that:

[...] although every interpretation has been made in the name of history or of science, there is a very broad spectrum of opinions as to what constitutes a plausible explanation. Linked with this is the idea of rational against unrational (faith-based) explanation. The most mundane (and ostensibly the most rational) natural explanations are those which involve a strong wind over a shallow inland lake or marsh. These are perhaps the easiest to accept in our modern world. And they are the types of explanation most favoured by professional biblical scholars, but by and large not by interpreters with a background in the natural sciences. Instead, natural scientists seem to prefer explanations which invoke more spectacular, or at least ostensibly more unlikely, elements. ${ }^{39}$

\footnotetext{
${ }^{38}$ HaRris, The Nature of Creation..., p. 189.

${ }^{39}$ Mark HARrIs, "How Did Moses Part the Red Sea?: Science as Salvation in the Exodus Tra-
} 
The natural explanations treat this account as belonging to Level 5 analysis. The literary and mythological approaches usually reject or are not interested in such an interpretation. If professional biblical scholars themselves are interested in treating this account as description of historical facts at all, they usually are inclined toward the natural explanations involving the presence of a strong wind over a shallow inland lake or marsh. Harris stresses the distinction between the approaches of scientists and biblical scholars. ${ }^{40}$ According to Harris, scientists are more inclined toward literal interpretations, influenced by their own fields of study, of particular accounts presented in the biblical texts, while the biblical scholars tend toward more symbolic or metaphorical reading of the same passages.

In his articles, Harris usually describes both approaches; he seems, however, to be more inclined toward the critical approach, along the lines suggested by H.H. Rowley. ${ }^{41}$ This approach is pluralistic in the sense that it combines literary, historical and scientific approaches. In fact, it seems to be postmodern in character as there is no single truth to be discovered. Harris affirmatively quotes Johnstone, writing that "Truth is not so much a once-for-all given as the production

dition”, in: Axel Graupner and Michael Wolter (eds.), Moses in Biblical and Extra-Biblical Traditions, de Gruyter, Berlin — New York 2007, p. 25 [5-31].

40 "An interesting difference becomes apparent between scientists and theologians over the ways in which they handle reality and metaphor. Modern scientists tend to adhere to stronger forms of realism regarding their fields of study than do biblical scholars and theologians. Critical biblical scholars in particular exhibit a high degree of caution towards literal reality claims made from their data, especially when those data are expressed in the heavily-coded symbolisms and metaphors of apocalyptic" (Mark HARRIS, "Will Resurrection Be a Law of Nature?: Science as Divine Action at the End of the World", in: Louise Hickman (ed.), Chance or Providence?: Religious Perspectives on Divine Action, Cambridge Scholars Publishing, Newcastle upon Tyne 2014, pp. 25-26 [21-44]). Analysing the Sea Event of Exodus 14, he indicates that "Most scientists appear to take the claims of the narrative at face value, and use it to put forward astonishing and imaginative (but still naturalistic) «explanations». This will become clear shortly, in the review of interpretations of the Sea Event. To reiterate, biblical scholars tend to look to mundane and naturalistic explanations, while natural scientists - who by definition are concerned with the mundane and naturalistic - often look to the miraculous and spectacular" (HARRIS, "How Did Moses Part the Red Sea...”, p. 7). The term "miraculous" used by Harris in his article in relation to the explanations proposed by scientists, should be understood as describing very improbable and spectacular natural factors, rather than as a reference to the supernatural factors as such (see Harris, "How Did Moses Part the Red Sea...”, pp. 8-17).

${ }^{41}$ See Harris, "How Did Moses Part the Red Sea...", p. 24. 
of meaning through the unending competition of voices in dialogue. The recognition of this compositeness is not an impoverishment but an enrichment of the appreciation of the biblical account". ${ }^{42}$ The notion of truth as something being produced rather than discovered is compatible with the postmodern approach. According to Harris, "Johnstone is absolutely right: even when considering the Sea Event alone, the Bible's fundamentally pluriform witness to it should be affirmed, not squashed into another, more uniform, pattern which it almost certainly never possessed. The pluriform witness is the key [...]". ${ }^{43}$ The "pluriform witness" is described by Harris as follows:

A good example of the solution which I have in mind comes with the resurrection narratives in the four gospels. Each is an attempt, by means of narrative, to explain in the medium of words and human concepts, what is ultimately inexplicable, even though, crucially but paradoxically, it involves material reality (a human body). And each is notably different. The evangelists grasp at the truth using human concepts which are on the verge of their and our understanding. My point is that both literary and scientific models of the Sea Event can be seen to operate in the same way - they complement each other, since each offers a different but incomplete view.

[...] Each explanation can and should be critiqued and judged on various levels, including rationalism, geographical and historical likelihood, and theological significance. But the point which I have tried to make is that a fully critical interpretation cannot be achieved by selecting one explanation over another on the grounds of rationalism, but rather by holding a plurality of explanations in creative tension. ${ }^{44}$

Hence, the fully critical interpretation as advocated by Harris involves both scientific and theological (especially critical literal and historical) analysis. It includes both the empirical facts and the meaning of what has happened. Importantly from the point of view of this article, both scientists and many theologians reject the explanations referring to a supernatural intervention in the sense of Level 3-5 statements present in the literal interpretation of this Biblical event. As Harris puts it, "[...] the explanations favoured by scientists are at heart rational

\footnotetext{
${ }^{42}$ William Johnstone, "Review of Humphrey's The Miracles of Exodus", Journal of Semitic Studies 2005, no. 50, p. 378 [373-379] (cited in: Harris, "How Did Moses Part the Red Sea...", p. 29.

${ }^{43}$ Harris, "How Did Moses Part the Red Sea...”, p. 29.

${ }^{44}$ Harris, "How Did Moses Part the Red Sea...", pp. 29-30.
} 
explanations, since they stem from well authenticated and well-established natural processes". ${ }^{45}$ Many biblical scholars are, in the name of rationality, also interested in explanations that avoid references to miraculous supernatural action, aiming at consistency with the scientific accounts. That is why all these explanations described by Harris, both scientific and those proposed by modern biblical scholars, contain no reference to the direct special supernatural action of God. The fully critical interpretation or the pluriform witness approach also seems not to include supernatural intervention as inconsistent with the scientific approach.

Harris's treatment of the problem of the ascension of Christ is also inspired by approach present in Gadamer's postmodern ideas. ${ }^{46}$ In the context of the analysis of the relations between science and religion, Harris is open about applying Gadamer's ideas (forming an essential part of the postmodern approach to the problem of truth) and quotes Gadamer in his analysis of the limits of science:

One potentially useful hermeneutical strategy that allows science to come naturally into conversation with theological approaches to reality is that of Gadamer's "priority of the question". In Truth and Method Gadamer warns against the imperialist inclinations of the natural sciences, and of their tendency to subsume all within their sway [...]. Gadamer insists that science performs its most effective task when it understands its limitations $[\ldots]$.

[...] against the tendency of science to be the master of all that it surveys (largely by casting the world into its own "explanatory" mould), Gadamer points out the creative power of dialogue. ${ }^{47}$

The notion of dialogue is sometimes used by naturalistic theists to describe one of the proper relations between science and religion. ${ }^{48}$ Harris himself stresses the need to defy what he calls the imperialist inclinations of science. On

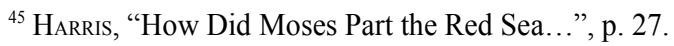

${ }^{46}$ See Mark Harris, "Science, Scripture, and the Hermeneutics of Ascension", Theology and Science 2014, vol. 12, no. 3, pp. 201-215.

${ }^{47}$ Harris, “Science, Scripture...," pp. 203-204.

${ }^{48}$ See, for example, BARBour, When Science Meets Religion.... See also the title of the book edited by Barbour: Ian G. Barbour (ed.), Science and Religion: New Perspectives on the Dialogue, Harper \& Row, New York — Evanston — London 1968.
} 
the other hand, he also indicates that the theological approach can be too metaphorical and omit certain important aspects of the issues at hand. In fact, both science and theology have an important role to play in terms of the dialogue:

[...] from a scientific perspective most theological approaches are often too ready to resort to "metaphor" and "mythology" [...]. It is therefore the task of science to keep the dialogue active. If, in other aspects of the science-theology field, it is science which is leading the way and theology which is reactive, then the roles are reversed here. Discussion of ascension becomes the point of redress, where any tendency towards scientific imperialism is reversed, and science must learn to ask the appropriate questions in order to help theology to advance the dialogue $\left[\ldots . . .{ }^{49}\right.$

When its imperialism is opposed and its limitations are factored in, science is able to advance the dialogue on the particular issues that theology is interested in. (In Conclusion, it is indicated that in the case of naturalistic theism, this is a kind of a "dialogue", in which theology accepts whatever the naturalistic science dictates).

Harris's scientifically motivated skepticism toward supernatural interventions - a major feature of the classical Christian theism - is most visible when he compares the cult of Father Pio with the interests in horoscopes or the UFO. Invoking Mark Corner, Harris writes that

[... even in this age of science, belief in the miraculous is still widespread, as is shown by the popular cult of Padre Pio, for instance, and there is extensive devotion to horoscopes and alternative [...] affirmations of spirituality. One may even add belief in UFOs and conspiracy theories as other aspects of "faith" at play in our modern world which demonstrate that we are not all as thoroughly skeptical of unproven ideas as scholars might think. ${ }^{50}$

Apposing statements on miracles of Father Pio with statements on UFO or horoscopes clearly shows Harris's attitude toward an important subset of the traditional Christian beliefs that include statements from Levels 4-5. Note, however, that those kinds of beliefs are not restricted to Christianity. Many religions contain rules and regularity statements referring to special divine action (also

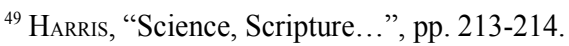

${ }^{50}$ Harris, The Nature of Creation..., p. 87.
} 
understood as performed by evil beings) in the natural world. These express themselves as assumptions behind the intercessory prayers to God or other supernatural beings; they include statements on the special role of the so-called holy pictures or places in communication with the sacrum and gaining special graces (e.g. a healing grace); these are assumed in the etiology of demonic possession assumed by exorcists, etc. This kind of skepticism is typical of naturalistic theism and is a consequence of the acceptance of the naturalistic assumptions expressed by Levels 2 and 3 statements. From this perspective, a large proportion of world religions seems to be excluded from the "open dialogue" between science and religion.

\section{Conclusion}

Naturalistic theists commonly accept two assumptions behind the "dialogue" between science and religion, the notion that is mentioned so willingly by Harris and other naturalistic theists. The first assumption is that only science has the competence to decide whether particular Level 4 and 5 statements are adequate, whereas the second is that the naturalist assumption behind science, expressed by Levels 2 and 3 statements, must be accepted. This approach is a consequence and expression of the division of epistemic competence mentioned above. These assumptions lead to skepticism toward literal interpretations of religious accounts of the events (Level 5) that are inconsistent with the scientific picture of the world. Even if there are statements from the empirical levels that are important in terms of religion, it is science that theology must follow when accepting or rejecting the literal meaning of such statements and not the other way round. This seems to be the way, in which naturalistic theists view the "dialogue" between science and religion.

Harris's analysis contains all the basic assumptions found within naturalistic theism. He does not take seriously the possibility that science can be mistaken in one of its basic assumptions, the one which is crucial for the relation between science and the Christian theism, namely the purely naturalistic model of any event in the natural world.

In his articles, Harris does put his knowledge of science and theology in use; however, it is mostly due to his proficiency in terms of biblical scholarship and 
the use of the hermeneutical approach in the analysis of the relation between science and religion that Harris distinguishes himself among other scholars and is able to continue developing a new, more advanced form of naturalistic theism. His attitude seems to be an effect of the mentioned assumptions and ways of analyzing the relations between science and religion, resulting in a plurality of interpretations and production of meaning, instead of more definite answers or a single truth that some might expect. In fact, in this approach it is scientific truths that seem to be treated as objective and definite. It is theology that seems to be more elusive and open to different interpretations, deep and vague meanings, which often is a result of it resigning from the literal interpretation, traditional in the Christian theism, of many accounts of miraculous events: sometimes these are rejected in the name of science. This rejection is consistent with the naturalistic assumptions behind science that are in conflict with the supernatural assumptions behind the traditional Christian theism.

Piotr Bylica

\author{
Mark Harris as a Naturalistic Theist: \\ The Perspective of the Model of Levels of Analysis
}

\begin{abstract}
Summary
Presently, naturalistic theism is the dominant position in the debate on the relation between science and religion, defending a thesis that the conflict between science and religion is only an apparent one. Also, this version of theism accepts the naturalist assumptions behind contemporary science and attempts to reformulate the beliefs held within the traditional Christian theism in order to present the religious view of reality as not conflicting with the scientific picture of the world. Certain assumptions behind Mark Harris's views on the relations between science and religion can be described as consistent with naturalistic theism.

The model of levels of analysis helps to analyze the most important themes found within naturalistic theism and show how these are described in the works of Harris. The model facilitates the identification of the relations between particular kinds of assumptions behind the position taken from the point of view of naturalistic theism in the debate on the relation between science and religion. The list of most frequently recurring assumptions - that are also important in Harris's writings - include: the general division of epistemic competence, which assumes theology (religion) to be competent in dealing with the metaphysical issues (Levels 1 and 2) and science to be the only one competent to deliver the empirical
\end{abstract}


statements describing processes and entities found within the empirical sphere (Levels 4 and 5); the acceptance of the naturalistic assumptions behind contemporary science (Level 2) and skepticism toward the religious notions found in the traditional Christian theism describing supernatural interventions and toward the dualist interpretation of human soul (Level 3). This leads to the acceptance of purely scientific, naturalistic, explanations of the events found within the empirical sphere and to skepticism toward the literal meaning of descriptions of empirical events (Level 5) that are not consistent with the anti-interventionist assumptions behind science.

Harris's acceptance of naturalistic theism in terms of the relation between science and religion and his use of the techniques found in the modern biblical scholarship have led him to the ideas of plurality of meanings and the lack of one definite truth with respect to the specific issues he deals with. From the point of view of MLA it is the rejection of supernaturalistic assumptions of the traditional Christian theism and the acceptance of the naturalistic assumptions of science that seems to be the cause of lack of definite truth in his theological explanations.

Keywords: theism, naturalism, naturalistic theism, science and religion, Mark Harris, biblical studies. 